\title{
Determination of the Herbaceous and Ligneous Plant Species Composition in Giron Masa Grazing Reserve, Kebbi State
}

\author{
Birnin-Yauri, H.B ${ }^{1}$. and S. Umar ${ }^{2}$ \\ Birnin-Yauri, H.B., Division of Sciences and Vocational Education, College of Basic and Advanced Studies, \\ Yelwa Yauri \\ S. Umar, Department of Agricultural Economics and Extension, Kebbi State University of Science and \\ Technology, Aliero
}

\begin{abstract}
The study determined the herbaceous and ligneous Plant Species in Giron Masa grazing reserve. The herbage samples were collected in July 2005-April, 2006 in four sub-seasons. The first collection was conducted in the early rainy season ERS (July), the second collection was done in the late rainy season LRS (October), the third collection was done in the early dry season EDS (January) and the fourth collection was conducted in the late dry season LDS (April). The data on herbaceous and ligneous species composition were analyzed by the use of frequency and percentages. Result of the herbaceous species identification has indicated a total of 26 species (14 legumes and 12 grasses) with the domination of two annual herbaceous legumes, senna obtusifolia and Hyptis suaveolens. A total of 24 ligneous species were identified in the reserve with 18 trees and 6 shrubs. The domination of combretum spp and Pilliostigma reticulatum in the ligneous species of the reserve indicated poor browse diet especially in the dry season. The herbaceous percent cover especially in ERS and LRS observed in the present study could be considered fair in meeting the grazing need of livestock especially if not over stocked.

Abbreviations

- ERS-Early rainy season

- LRS- Late rainy season

- EDS- Early dry season

- LDS- Late dry season

- TLU-Tropical livestock unit
\end{abstract}

\section{Background of the Study}

Herbaceous forage legumes belong exclusively to the sub-family papilionaceae, which is the main source of most of the pasture legumes (Agishi, 1985). Distributions of legumes and factors affecting their dispersal have not been documented as the grasses. Legume such as Stylosanthes, Desmodium, Phaseolus, Centrosema, Leucaena, Calopogonium, and Taramnus are indigenous to tropical America with centre of origin in Central America (Bermudez, 1960). The Sudan Savanna and the Sahel around Sokoto, Katsina, Kano, Bauchi and Borno States with an annual rainfall of $500-875 \mathrm{~mm}$ favour the growth of annual grass species such as Cenchrus, Ctenium Schoenefeldia, Eragrostis, Andropogon and species of Aristida and Laudetia. The sahel mainly harbours Aristida stipoides, Schoenefeldia gracilis and Cenchrus biflorus (Le Houero, 1980; Adegbola, 1982). Most of the species are highly rated in terms of forage value. Some of these indigenous legumes such as Calopogonium muconoides, Clitoria ternate, Alysicarpus vaginalis, Fruticosa and Vigina vexillat are widely grown for pasture (Agishi, 1985).

In Nigeria and many other countries in the tropics, low yield, poor quality and inefficient utilization of natural pastures are some of the factors limiting the level of livestock production (Okeagu and Akinola, 1982). The low protein content of many types of forage is most critical to livestock production, closely followed by total dry matter supply and water (Agishi, 1985). It was reported that expansion of cropland into rangeland at an annual rate of 2.5 to 3\% (FAO 1996) and the shortening or abandonment of fallow periods (Ramaswamy and Sandars, 1992) have greatly reduced pasture availability in semi-arid Africa. As population increases, cultivators and agro-pastoralists put more land into cultivation and the quantity and quality of the remaining pasture land and the productivity of the herds decline (Mohammed-Salim, 1998).

Giron Masa grazing reserve is one of the nationally identified and gazetted grazing reserves in Kebbi State, where appreciable number of livestock converge annually during the crop growing season. This area falls within the northern guinea Savannah region, where nutritional requirement of livestock is rarely met due to inadequate and poor quality pasture especially in the dry season. Giron Masa grazing reserve is not devoid of most of the constraints reported and no attempt has been made in the past to evaluate such quality parameters, which will serve as reference point for other researchers. In view of this the present study was designed to determine the herbaceous and ligneous species composition in the reserve. Pastoralists and farmers throughout 
the sahel commonly face serious food shortages and even the possibility of starvation. Crop yields, herd productivity and their relative terms of trade are highly variable due to unpredictable fluctuations in rainfall and other environmental factors (Breman and Traore, 1986). Malami, 1994 reported that overgrazing leads to extinction of decreased species with a consequent increase in invader species, which are less desirable and unpalatable to the animals. This is particularly more so in an ecologically fragile region where climatic condition is unfavorable for efficient pasture production.

\section{Description of the Study Area}

\section{Methodology}

The study was conducted at Giron Masa grazing reserve located 30km from Yauri town. It is situated in Shanga Local Government Area (LGA) South most tip of Kebbi State. The reserve lies between latitude $11^{\circ} 06^{1}, 483^{\prime \prime} \mathrm{N}$ and longitude $04^{\circ} 42^{1}, 356^{\prime \prime} \mathrm{E}$. The vegetation is that of typical northern guinea savanna, which consist of an almost continuous grass cover of not less than 1 meter in height. There are clumps of interspersed tree cover which averages 25-50 feet in height with a mixture of fine-leaved thorny trees and broad leaved deciduous species. The thick tree cover is found along streams and depressions (Udu, 1991). The mean annual rainfall of the area is $1040 \mathrm{~mm}$. The rainy season last for 5-6 months, between April/May to October with heaviest amount in September, Temperature ranges from a minimum of $15-24^{\circ} \mathrm{C}$ in December/January to a maximum of $32-39^{\circ} \mathrm{C}$ in April/May. Relative humidity varies between $28-40 \%$ in the morning to $21-33 \%$ in the afternoon. The soil consist of well drained sandy loam soil and clay or clay loam soils on the fadama site. It is rich in organic matter especially the nomads settled spots ((Yauri Metereological Station 2007).

\section{Method of Data Collection}

The study was conducted in July 2005- April, 2006 in four sub-seasons. The first collection was conducted in the early rainy season ERS (July), the second collection was done in the late rainy season LRS (October), the third collection was done in the early dry season EDS (January) and the fourth collection was conducted in the late dry season LDS (April). Data were collected using three transects demarcated approximately 1 kilometer apart. The herbage samples were collected by using $1.0 \mathrm{~m}^{2}$ wooden frame (quadrant). 12 sampling points were kept at an interval of 500 meters apart along each transect. At each point, the wooden frame was randomly thrown 5 times, thus making a total of 60 throws for each transect and a total of 180 throws for the three transects.

\section{Method of Data Analysis}

In each plot, ligneous species were counted once in the first collection within a radius of $56.4 \mathrm{~m}(1$ hectare). Percentage cover was also determined by taking average percentage visual observation of three observers at each point. The data on herbaceous and ligneous species composition were analyzed by the use of frequency and percentages

\section{Results of the Study}

From the table, the results on herbaceous legume composition indicated that, 14 species were identified. The legume species with the highest composition identified was Senna obtusifolia $(24.02 \%)$ while the lowest identified legume were Ipomea eriopcarpa and Sida acuta (0.19\%) each.

Species composition of Herbaceous Legume at Giron masa grazing reserve

Table I: Results of herbaceous legume species composition of Giron Masa grazing reserve

\begin{tabular}{llcc}
\hline Species & Common Names & Frequency & $\%$ \\
\hline Senna obtusifolia & Tafasa & 129 & 24.02 \\
Hyptis suaveolens & Busuru & 92 & 17.13 \\
Cassia mimosoides & Bagaruwan kasa & 72 & 13.41 \\
Alysicarpus vaginalis & Gadagi & 72 & 13.41 \\
Crotalaria retusa & Gujiyar Awaki & 53 & 9.87 \\
Monechma ciliatum & Danfarkami & 22 & 4.10 \\
Sida rhombifolia & Namijin hankufa & 17 & 3.17 \\
Indigofera hirsute & Masahe (Kai-kai) & 13 & 2.42 \\
Oldenlandia herbacea & Rinin samari & 9 & 1.68 \\
Waltheria indica & Hankuwa & 4 & 0.75 \\
Tridax procumbens & Harawan Zomo & 3 & 0.56 \\
Ipomea eriopcarpa & Yaryadiya & 1 & 0.19 \\
Sida acuta & Miyar tsanya & 1 & 0.19 \\
Total & & 537 & 100
\end{tabular}

Species composition of herbaceous grasses at Giron Masa grazing reserve 
From the table, the results of herbaceous grass composition indicated that, 12 species were identified. The grass species with the highest composition was Brachiaria lata (59.25\%) while the lowest grass was Andropogon gayanus and Rottboellia cochinchinensis (0.25\%) each.

Table II: Results of species composition of herbaceous grass at Giron Masa grazing reserve

\begin{tabular}{llcc}
\hline Species & \multicolumn{1}{c}{ Common Names } & Frequency & $\%$ \\
\hline Brachiaria lata & Shebu & 237 & 59.25 \\
Hyperrhenia involuctrata & Sharnai (Cuci) & 39 & 9.75 \\
Brachiaria jubata & Burgu & 33 & 8.25 \\
Dactyloctenium aegyptium & Gude-Gude & 33 & 8.25 \\
Eragrostis tremula & Bubburwa & 17 & 4.25 \\
Pennisetum pedicellatum & Kyasuwa & 13 & 3.25 \\
Echinochloa colona & Gamshe & 10 & 2.50 \\
Fimbristylis ferruginia & Askan Wanzan & 8 & 2.00 \\
Seteria pallide-fusca & Geron tsuntsaye & 5 & 1.25 \\
Digitaria horizontalis & Harkiya & 3 & 0.75 \\
Rottboellia cochinchinensis & Gyazama & 1 & 0.25 \\
Andropogon gayanus & Gamba & 1 & 0.25 \\
Total & & 400 & 100 \\
\hline
\end{tabular}

\section{Species composition of ligneous tree at Giron Masa grazing reserve}

From the table, it was indicated that 18 ligneous tree species were identified. The tree species with the highest composition were Acacia hockii (18.35\%) and lowest were Entada sudanica and Vitex cienkowskii (0.92\%) each.

Table III: Results of species composition of ligneous tree at Giron Masa grazing reserve

\begin{tabular}{llcc}
\hline Species & \multicolumn{1}{c}{ Common Names } & Frequency & $\%$ \\
\hline Acacia hockii & Bakar kaya & 20 & 18.35 \\
Butyrospernum parkii & Kade & 9 & 8.26 \\
Detarium microcarpum & Taura & 4 & 3.67 \\
Acacia Senegal & Akwara & 11 & 10.09 \\
Terminalia macroptera & Baushe & 9 & 8.26 \\
Burkea Africana & Kiryar dutsi & 4 & 3.67 \\
Annona senegalensis & Gwaddar daji & 2 & 1.84 \\
Centauria senegalensis & Danya & 6 & 5.51 \\
Anogeissus leiocarpus & Marke & 7 & 6.42 \\
Tamarindus indicus & Tsamiya & 7 & 6.42 \\
Odina barteria & Faru & 6 & 5.51 \\
Sterculia setigera & Kukuke & 7 & 6.42 \\
Daniellia olivera & Maje & 5 & 4.59 \\
Boswellia dalzielli & Hannu & 5 & 4.59 \\
Diospyros mespiliformis & Kanya & 3 & 2.75 \\
Parkia filicoidea & Dorawa & 2 & 1.84 \\
Vitex cienkowskii & Dunya & 1 & 0.92 \\
Entada sudanica & Tawatsa & 1 & 0.92 \\
Total & 100 & 109 & 100 \\
\hline
\end{tabular}

Species composition of ligneous shrub at Giron Masa grazing reserve

Table 4: Species composition of ligneous shrub at Giron Masa grazing reserve

\begin{tabular}{llcc}
\hline Species & \multicolumn{1}{c}{ Common Names } & Frequency & \% \\
\hline Combretum verticellatum & Taramniya & 35 & 40.70 \\
Pilliostigma reticulatum & Kalgo & 30 & 34.88 \\
Grewia mollis & Dargaza & 10 & 11.63 \\
Guira senegalensis & Sabara & 6 & 6.98 \\
Cochlospermum tinctorium & Balge & 4 & 4.65 \\
Balanites aegyptiaca & Aduwa & 1 & 1.16 \\
\hline Total & & 86 & 100 \\
\hline
\end{tabular}

From the table it was indicated that 6 ligneous species were identified with Combretum verticellatum (40.70) as a dominant species of the ligneous strata while Balanites aegyptiaca $(1.16 \%)$ was the lowest in occurrence.

\section{Conclusion}

Results on herbaceous composition indicated a domination of unpalatable species in all parts of the reserve. The domination of two annual herbaceous legumes, senna obtusifolia and Hyptis suaveolens could be as a result of over grazing of livestock, which consequently affected the species composition. This has been confirmed by Breman and Cisse 1977, Breman et al., (1979) who reported that intense grazing may bring about 
considerable changes, often encouraging the invasion of annual herbs such as Zornia glochidiata, Tribulus terristris and unpalatable species such as senna obtusifolia and Elionurus elegans. The domination of Brachieria lata was recorded in the ERS, but due to its faster physiological maturation, it senesce dried up before the end of the rainy season.

The domination of combretum spp and Pilliostigma reticulatum in the ligneous species of the reserve indicated poor browse diet especially in the dry season. This is because of the high level of polyphenolic compounds including tannins, which is abundant in combretaceae. The tannin precipitates dietary protein thereby reducing their digestibility and making them less available to animals (Le Houerou 1980). Although pastoralist have indicated the relevance of Pilliostigma pods as a browse source during the dry season. Among the browse species preferred by cattle, only Grewia mollis, Balanites aegyptiaca and Acacias of lower frequencies are found in the present study. The Acacias, forms the most important browse during the dry season when the herbage quality deteriorates as confirmed by Agishi (1985) in Sudan zone. This indicated that the only alternative left to pastoralist is migration during the dry season.

The herbaceous percent cover especially in ERS and LRS observed in the present study could be considered fair in meeting the grazing need of livestock especially if not over stocked. In Zamfara reserve, high stocking densities during the rainy season have been reported by Schafer et al., (1998) and Hoffman et al., (1998). Thus leading to decrease of some palatable plant species as a result of overgrazing and trampling, EDS and LDS recorded very low herbaceous percent cover due mainly to extensive drying of herbage, termite destruction and bush burning observe during the studies.

\section{References}

[1]. Agishi, E. C. (1985), Forage Resources of Nigerian Range Lands: In: Adu, I. F. (ed) National Conference, on Small Ruminant Production in Nigeria, NAPRI, Zaria, 6-10 ${ }^{\text {th }}$ October, 1985.

[2]. Adegbola, A. A. (1982), Forage Resources and Beef Production in Nigeria, In: O. A. Osinowo J. Ikhatau and W. O. Ehoche (eds). Beef Production in Nigeria, Proceedings of National Conference on Beef Production, July, 1982 Kaduna, Nigeria, National Animal Production Research Institute, A. B. U. Zaria; Nigeria. Pp. 137-162.

[3]. Breman, H. and A. M. Cisse (1977). Dynamics of Sahelian Pastures in relation to drought and grazing. Oecologia, 28: $301-315$.

[4]. Breman, H., A. M. Cisse, M. A. Djiteye and W. T. Elberse (1979). Pasture dynamic and forage availability in the sahel. Israel Journal of Botany, 28: 227-251.

[5]. Breman, H., Traore, N. (eds) (1986). Analyse des conditions de L'e'levage et propositions de politiques et de programmes Burkina Faso. Sahel D. (86) 300 OECD/Crbss/Club du Sahel.

[6]. Breman, H., Traore, N. (eds) (1986). Analyse des conditions de L'e'levage et propositions de politiques et de programmes Burkina Faso. Sahel D. (86) 300 OECD/Crbss/Club du Sahel.

[7]. Hoffmann, I., C. Willeke-Wetstein and C. Schafer (1998). Description of grazing eco-system in north western Nigeria using environmental indicators. Animal Research and Development, Vol. 48, Institute for Scientific Co-operation, Tubingen Federal Republic of Germany. Pp. 69-83.

[8]. Le Houerou, H. N. (1980). Composition Chemique et valeur nutritive des fourrages Ligneux en Afrique Tropicale Occidentale In: Le Houerou, H. N. (ed). Les fourrages, Ligneux en Afrique - et al actuel des connaissances. ILCA Addis Ababa, Ethiopia. Pp. 259284

[9]. Malami B. S. (1994). Survey and Quality Evaluation of some Grazing Reserves in Sokoto and Kebbi State of Nigeria. M. Sc. Thesis, Department of Animal Science, University of Nigeria Nsukka, Nigeria. 193pp.

[10]. Mohammed-Salim, M. A. (1998). Nutrient balance patterns in African Livestock Systems. Ecosystems and Environment 71: 241254.

[11]. Ramaswamy, S. and J. H. Sanders (1992). Population Pressure, land degradation and Sustainable Agricultural Technologies in the Sahel. Agricultural Systems, 40: 361-378.

[12]. Schafer, C., Hoffmann I. and Steinbach (1998). The role of traditional livestock husbandry in the supply of milk, meat, and drought power in the north west of Nigeria. Animal Research and Development vol.46: Institute for Scientific Cooperation.

[13]. Udu, R. K. (1991). Geographical Regions of Nigeria Longman Ltd. Pp. 21-27.

[14]. Yauri Metereological Station (2007). National Meteorological Agency, Kebbi State. 